\title{
The Coordination Problem in the Stockholm School
}

\author{
Romar Correa \\ DOI 10.1515/jheec-2015-0016
}

Abstract: We revisit the Stockholm School of Economics with first principles. The objective is a rendition of a cumulative Myrdal-Wicksell process. To that end, we derive heterogeneous responses of consumers and producers to changes in the state of the world and define a Myrdal-Keynes equilibrium.

Keywords: monetary equilibrium; cumulative processes; the coordination problem

JEL Classification: B22; E31, E42

\section{Introduction}

It is accepted that the Stockholm School of Economics was not a progressive research programme because the intuitions of its progenitors like Erik Lindahl, Erik Lundberg, and Gunnar Myrdal went ahead of the technical language of the time. Extensive use was made of verbal reasoning, for example, in the construction of causal sequences (Lindahl,1970, is a wealth of complex illustrations) flowing from the divergence of the market rate of interest from the natural rate. These chains had an open-ended character leaving the meaning of equilibrium and disequilibrium unclear. Due attention was not paid to, in modern parlance, the tension between the micro and the macro. The giants mentioned above were sensitive to the fact that a leap of faith is required to move from the equilibrium method of partial analysis to the study of a monetary economy. The device of applying a multiplicative factor to a representative agent would not do (Lundberg, 1937, p.9). Myrdal was pessimistic about the integration of monetary theory and general equilibrium theory. It did not seem possible to him to meaningfully integrate time contracts, particularly credit contracts, expressed in monetary units and the theory of value. The quantity theory was no panacea for it could not explain the influence of credit on price relations rather than just the price level (Myrdal, 1962, p.16, italics in the original). The former depended both on the supply of and the demand for credit.

According to David Laidler (2007), the specification of the problematic as one of the coordination of individual choices was the special contribution of Knut Wicksell (see also 
Tobon \& Barbaroux, 2015). We traverse the path traced by subsequent scholars. The context is a critique of Wicksell's analysis in independent real and money terms. Indeed, the so-called Wicksell connection is the treatment of themes in which the distinction between the natural and market rate has dropped and where 'the' rate of interest fails to keep the economy on an intertemporal equilibrium path (Sandelin \& Trautwein, 2008, van den Hauwe, 2015). The rate of interest is not, in general, able to equalise Savings and Investment. The explanation lies in the dispersion and acquisition of information. Myrdal is the hero of the enterprise but, in the appraisal of some scholars, while he constructed disequilibrium monetary sequences, he too paid no attention to the disequilibria resulting from the absence of coordination in the plans of agents (Faxén, 1991; Siven, 1991). Our reconstruction is inspired by the independent sympathies of GLS Shackle and Axel Leijonhufvud.Shackle's precept that the future is full of novelty and surprise is an important plank of the Post Keynesian research strategy. Leijonhufvud, on the other hand, is regarded as a maverick within the mainstream because his "corridor hypothesis" does not exclude Walrasian equilibria within the basin of stability of an economic system. Shackle wrote an elegant foreword to a Wicksell classic (1954) and, in the opinion of some, was well positioned to carry the sequence method forward (Barber, 2009). We borrow from him the single axiom that the future is unknown and unknowable. The contribution of Leijonhufvud, it is well known, is the driving of a thick wedge between Keynesian Economics and the Economics of Keynes as well as the development of the Wicksell-Keynes connection. With the former enterprise Professor Leijonhufvud showed that the General Theory was innocent of wage- and interest-rate rigidity. Also, the interest-inelasticity of investment and savings are not to be found in that classic (Leijonhufvud, 1969). It is perfectly consistent for any model on the lines of the Economics of Keynes to be grounded in the maximization of utility and profits. Both present and future price incentives are effective. Finally, prices and interest rates move in response to excess demands in the corresponding markets. In a collection of essays titled Information and Coordination Leijonhufvud proposed that macroeconomics is best treated in systems theory fashion. The whole might generate outcomes unintended by the parts. For instance, each market is represented by two 'control variables', a price and a quantity. When the outcome differs from the equilibrium value, a negative feedback or deviation-reducing process must occur. The 'Walrasian homeostat' is one in which price responds to the sign of excess demand. Another servo-mechanism is the 'Marshallian homeostat' where quantities adjust. The problem is that while both 'thermostats' might work well independently, when thrown together the signals might scramble, the outcome being deviation-amplification or positive feedback. While scholars would be interested in the characteristics of the economy within the stability "corridor", Leijonhufvud was more concerned with the economy outside it. His conjecture was that the modern monetary economy was tossed between deviation-amplifying loops. Incorporating Shackle and Leijonhufvud in an otherwise-standard model we meet only one of the three criteria of the definition neoclassical (Dequech, 2012). While we 1) assume rationality, 2) our economy does not tend toward an equilibrium which may or may not be unique, and 3) our notion of uncertainty cannot be axiomatized. Other aspects of generalised systems theory (GST) include the axiom that the money economy and the real economy are ontologically identical and, put colourfully, both the government and economic agents do not know that the sun will rise tomorrow (Kakarot-Handtke, 2010). The economy, according to Post Keynesians, is a network of integrated real and monetary circuits (Dequech, 2012: Lavoie, 2012). Even as a thought experiment there is no barter economy 
to which money must be attached. Monetary and real variables are determined jointly both in the short run and the long run. The task of the monetary theory of production is to explicate settlements procedures and the operation of the payments system. Reservations about the representative agent of neoclassical economics are by now routinely expressed and models with heterogenous agents are being written. We follow Leijonhufvud in the assumption that agents are different at least because they possess different information sets. In that case, the economic problem is to concatenate the different plans. The maladjustment in our case rests on money in the information sets of consumers. The element is absent in the information sets of entrepreneurs. In short, we are inspired by an unrealised Myrdal-Keynes research programme (Barber, 2009). The two planks of the agenda are the ex ante-ex post distinction (Myrdal) and the appreciation that decisions to save and decisions to invest are made by different people (Myrdal and Keynes).

We pursue this line of enquiry against the modern neo Wicksellian conception that coordination failures are the outcome of wage and price rigidities. Michael Woodford (2005) has written the definitive work. He proclaims, on analytical and empirical grounds, that the short-term interest rate is the control variable par excellence in the hands of the monetary authorities and the money supply has lost that pride of place. There is, here, the chicken-or-egg question of whether models drive policy or it is the other way around. In one reading, it is the stranglehold exerted by the Dynamic Stochastic General Equilibrium (DSGE) model on the profession that has resulted in an overnight rate being the policy variable of choice. On the other hand, some believe that the DSGE model only rationalises long-standing practice by central bankers on that front. In either case, however, many insiders have observed that this claim is false. Central Bank officials closely track monetary aggregates. Woodford's case is partly based on the instability of the functions whose intersection determines equilibrium in the money market. However, the demand for or supply of money functions are not the issue here. Money is the rubric of society that emerges behind the backs of the agents, so to speak. Thus, even if we concede that the monetary base is unimportant, borrowing and lending is not (Goodhart, 2009; Laidler, 2006). Indeed, it is especially the atomistic agents of microeconomics that do not have marketable assets and cannot borrow except at exorbitant interest rates. They are liquidity-constrained with present income equal to expected income. The relaxation of the constraint depends upon the willingness of the banks to intervene. Therefore, the rate of growth of bank lending to consumers and firms is not less important than a monetary aggregate. A change in the posture of banks as they become more or less risk averse will shift the constraints affecting private agents. Furthermore, there is a schedule of interest rates depending on the perceived riskiness of borrowers. In general, during a recession the returns on safe, liquid government debt decrease but risk premia rise. Reliance on a barometer like the Federal funds rate is hazardous because interest rates overall might rise or fall. The process goes into reverse in a recovery. Once again, the spanner in the macroeconomic works is the failure of 'the' interest rate to coordinate the plans of real investors like business firms and financial investors like savers (Mazzocchi et.al, 2009). As a result, cumulative processes might be engendered in prices (Wicksell), in output (Keynes), or both (Lindahl and Myrdal).

Our point of departure, then, is a reworking of the traditional Swedish insights with no more than the apparatus of elementary microeconomics. David Laidler (2012) would endorse this strategy of working out some implications of the Wicksell connection using the apparatus of microeconomics that was not available to Leijonhufvud. A postulate of Swedish period analysis is the "conjunctural" instability of capitalist economies 
(Lundberg, 1968, p.9). The notion embraces the systematic instability that affects entire economies and excludes the irregular fluctuations in production, employment, and trade that average out for the economy as a whole. The instability is more general than the rhythmic activity of business cycles. The conjuncture implies change in the economic environment that can assume a variety of forms and is different from the periodic succession of regular waves of production and prices. Of interest to the student of contemporary macroeconomics is the pronouncement, therefore, that the debate about whether the business cycle exists is a "sterile problem" (Lindahl, 1968, p.9).

In sequence analysis the more or less continuous distribution of individual characteristics within a unit period is disregarded. For the purposes of our model, the analysis of the influence of durable investment on development is carried out by selecting the time of construction as a unit period. At the beginning of a given period, plans are made and decisions with regard to production and consumption formulated. These plans ex ante are made on the basis of available data ex ante. The interactions between the actions flowing from the plans determines outcomes within the period. The special Swedish proposition that exchange takes place, conceptually, in the moment is consistent with the assertion that exchange is sequential (van Eaghen, 2014). The quid and the pro are separated by the passage of time. Dwelling on a point in time means that the two are tagged by different moments not that they coincide. These values ex post will, in general, be different from the values ex ante and after a certain time lag, defined by the unit period, new plans are made and executed and so on. The plan of the entrepreneur includes conceptions of the reactions of other entrepreneurs, of consumers, to changes in his price and output. These conceptions are assumed to mutually impact on each other. The functional relationship between these conceptions and plans will depend on the degree of competition (Lundberg, 1937).

\section{The conjuncture from a modern perspective}

\subsection{A Myrdal-Keynes Equilibrium}

Swedish macroeconomics of the thirties was founded on two notions of disequilibria that were connected. The disequilibrium between the nominal and the real interest rate could be translated into the divergence between ex ante savings and investment (Lundberg, 1996). Savings out of income is not equivalent to a command over capital goods. It is a nontrivial matter to investigate the conditions under which such a transformation is affected. Indeed, such an analysis is the crux of the theory of capital formation and business cycle research more generally (Lundberg, 1937, pp.138-139). A distinction has to be made, Lundberg reasoned, between savings in the form of cash balances and the purchase of new securities. Only in the latter form can savings be said to resemble a demand for capital goods in the form of a 'capital disposition' to procure finished capital goods produced in anticipation of future saving. In the form of bank deposits, on the other hand, savings assume a more passive and indirect character. At any rate, the link between savings and the real capital formation is not obvious and has to be worked out. The savings of a firm approaches the classical definition when, instead of being disbursed to shareholders, it is used to acquire new capital equipment. The 
limitations of the passive account of savings in the context of real time was recognised (Lundberg, 1937, pp.143-144). He argued that consumption and savings are alternative strategies in the sets of consumers. In like manner, the decision to save or invest is decided upon by the businessman on the basis of anticipated income. It is important to note that the Swedes did not share Keynes' belief in the primacy of investment. Savings play no less an important independent causal role. The identity of savings and investment ex post does not imply that the supply of saving cannot have an independent restrictive effect on investment during a boom (Lundberg, 1996).

Myrdal launched a nuanced critique of Wicksell's natural rate of interest (Myrdal, 1962, pp.49-53) and proposed, instead, its substitution by what he termed exchange value productivity. He went to the extent of labelling the concept metaphysical although their descriptions of the cumulative process were similar (Barber, 2009). Wicksell had borrowed Böhm-Bawerk's concept of the physical marginal productivity of the roundaboutness of production. The natural rate exists in an imaginary state without credit transactions. Economic subjects are assumed to adjust the time profile of their income streams by the exchange of real capital and commodities and by loan transactions in nature but not by loan and deposit contracts. Myrdal pointed out, however, that exchange values are not given a priori but only within the context of price formation by means of which the exchange value of productivity of waiting is determined. The latter, then, can only be computed by calculations that assume an abstract unit of account for the exchange values. If, furthermore, it is assumed that agents replace their loan and deposit transactions in the pure state with credit contracts made in the calculating unit, the unit acquires the properties of a monetary unit. In addition, productivity depends upon relative prices which are not stable. Also, the terms and conditions of credit contracts influence these relative prices and thereby the exchange value product of real capital. In sum, credit and the money rate of interest must be included in the definition of the natural rate of interest.

Our journey through the theory of value in traditional terms would begin thus (Shackle, 1967). At the beginning of the period under consideration, businessmen intend to sell a given array of goods to consumers. We deal with income-disposers first although they could be entrepreneurs as well in that function. In the interval they could draw down their stocks of money. Negative withdrawals of money from hoards is savings. A modern account would use mathematics which does not need to be defended even from a neoclassical perspective. It is only the axiom-theorem-proof strategy of Bourbaki that has found disfavour among Post Keynesian and others. Indeed, in the exchange between Walras and the mathematical greats of his time, scholars have discovered strong notes of caution voiced by the latter about the use of mathematics in economics (Turk, 2012). Specifically, they advocated an economic program that accepted the central role played by pure uncertainty in economic behaviour along with the appreciation that the real number line was an erroneous representation for the uniqueness of the past, present, and the future. Henri Poincaré, for instance, recommended the study of human conduct that was bereft of clairvoyance. Secondly, since the economic system is irreversible, a movement towards equilibrium cannot be ensured.

The textbook treatment begins with the problem of a consumer maximizing lifetime 
utility,

$U=\sum_{t=1}^{\infty} u\left(c_{t}\right)$

where $c_{t}$ is the flow of consumption at point $t$. We have ignored the discount rate for the sake of convenience but some reflections here are called for. Exponential discounting has come under fire recently helped by Paul Samuelson's protest that his invention was a frippery and was never intended to be taken seriously. Hyperbolic discounting has been proposed in its stead to reflect the fact that future dates differ substantively from the present from the viewpoint of decision making (see, for instance, Epper et.al., 2010). Likewise, past time points that generated the data for the present are each unique when looked at from the vantage point of the economic agent and are incomparable with the present. While the discount rate might be innocuous, discounting is not (Shackle, 1978). What were no more than obiter dicta about pure uncertainty in the General Theory, Shackle welded into a comprehensive macroeconomics. The spot rate is known today but, in one-period contracts, is effective only tomorrow. Agents contract on the basis of perfect information today. However, in the radical subjectivist view, the future is a blank plagued by unknowledge. In our notation, while $r_{t}$ is known to all agents, $1+r_{t}$ is an imponderable to a borrower/lender and we attach the superscript $c$ to denote the fact that it is the consumer who is performing the calculations. The ex ante and ex post span which consists of data today and outcomes tomorrow is different from the rate of interest expected in $t+1$. Herbert Simon observed that expectation formation is but one of a set of strategies to contend with fundamental uncertainty. In any case, $1+r_{t}^{c} \neq r_{t+1}^{e}$. The first-order condition is the well-known intertemporal Euler equation given by

$u^{\prime}\left(c_{t+1}\right) / u^{\prime}\left(c_{t}\right)=1 / 1+r_{t}^{c}$

So far with Woodford's programme which eschews the derivation of explicit demand and supply functions. The old Wicksellians proposed a "new definition of income" according to which income, and the consumption that flowed therefrom, was a stream of interest accruing as a result of the operation of the time factor (Lindahl, 1968, p.142). Conversely, the rate of interest is of central importance because it embodies the exchange relation between commodities at two points of time (Myrdal, 1962, p.23). Like Myrdal, all the members of the Swedish school roundly critiqued Wicksell's natural rate of interest deriving from marginal physical productivity considerations (Weber et.al., 2008). In particular, much effort was expended on Wicksell's third condition of monetary stability; that the definition of equilibrium, defined by equality between the natural and money rate of interest, necessarily includes constancy of the prices of consumer goods. The optimal interest rate, per contra, they argued, is a function of actual and anticipated prices. Thus, we write the rate of interest as an implicit function of the state variables in the present and the future. By the implicit function theorem, the relationship is as follows: $r_{t}^{c}\left(c_{t+1}, c_{t}\right)$. 
must cause an appropriate change in the value of ${ }^{1+r_{t}^{c}}$ in order for the optimality condition to continue hold. For exegetical reasons just cited, we transfer the reasoning straightforwardly to the dual of the consumer problem, using the same function in a $r_{t}^{c}\left(p_{t+1}, p_{t}\right)$.

harmless abuse of notation, ${ }_{-}{ }_{-}$Since the notion of exchange rate productivity that Myrdal advanced was based on relative prices "which cannot be assumed to be stable" (Myrdal, 1962, p.49), we need to derive the following property of the maximum value function: We know that the indirect utility function is homogenous of degree zero in prices and cash. Since a microeconomic description requires the impact on the budget constraint to be explicit (Mazzocchi et.al., 2009), denoting money balances by $m$, we have

$p_{t} c_{t}+p_{t+1} c_{t+1} / 1+r_{t}^{c}=m_{t}+m_{t+1} / 1+r_{t}^{c}$

Thus, by virtue of its present extension, the indirect utility function, $v\left(p_{t+1}, p_{t} ; m_{t+1}, m_{t} ; 1+r_{t}^{c}\right)$, is homogenous of degree zero in the price vector, the cash vector, and (one plus) the rate of interest. The novel feature here is the incorporation of the current interest rate in the maximum value function. In the co-movement of the triple in the vector, we offer the multiplicative factor, Myrdal (Myrdal, 1962, p.11, italics in the original) envisioned by means of which the relative prices of a microeconomic model can be transformed into absolute money prices. Indeed, banks or Central Banks must implement the changes in the cash infusions or deductions over time that accompany, pari passu, any changes in the price vector and the corresponding optimizing interest rate. In other words, while $r$ is a real number, its dynamic must tracked one-to-one by prices and money over time to leave the utility of the consuming agent unimpaired The stance of the monetary authorities and the banking system must, according to members of the Stockholm School, be 'passive' The model was predicated on the existence of freie Valuta (free currency) (Myrdal, 1962, p.109). Banks were not assumed to operate under any constraints. Financial intermediaries were viewed as black boxes keeping credit conditions unchanged. Changes in the price level are "primary" in the sense that anticipations of the future price are the causes of their actual change (Lindahl,1970, p.147). In modern terminology, price movements are selffulfilling. Furthermore, the money in the model is unlikely to be private money and must be government money. One reason is that in the mechanics of payments both payer and payee must form correct assessments of the market value of the instrument of exchange. It is possible that the costs of investigation far exceed the rate of return promised by the paper. Fiat money with a stable value in terms of output is "information-insensitive" (Calvo, 2012). The implication of the Hahn problem is that the output price of fiat money might be zero or volatile. That is not the case, however, if the private sector posts prices and wages in money in the period under consideration and will change quantities to ensure equilibrium in the output market.

It is worthwhile to emphasise the distinction between money here and money in the neoclassical model. In general equilibrium analysis goods are valued in terms of a unit of 
account and the equilibrium assigns to each good a price, in terms of this unit, at which its demand equals its supply. It is only when a substantive means of purchase like bank money which does not represent the list of goods and services is introduced that aggregate demand and supply might not be equal (Shackle, 1967). Money in the pockets of consumers and workers permits the deferment of specific choices. At the same time, the introduction of money here and not in the firm choice problem is only a matter of following in the steps of the textbooks. Indeed, in Lindahl, demand for money equals deposits and is determined by the firm's demand for loans which equals deposits (Boianovksy \& Trautwein, 2006).

The accumulation of plant and machinery follows in the canonical fashion. Thus, an output flow $y_{\mathrm{t}}$ is generated by a production function $f\left(k_{t}\right)$ with capital $k$ the only factor of production. In time-honoured fashion, the entrepreneur is assumed to borrow in order to finance the acquisition of capital. In addition to the first order condition above, the solution to the problem includes the well-known equality of the marginal product of capital with the interest rate. In Wicksell's language, the natural or real rate of interest

$r_{t}^{f}=f^{\prime}\left(k_{t}\right)$

Contemporary scholars, respecting the modern distinction between the short-run and the long-run aggregate supply curve, have revived the Swedish 'neutral' interest rate and have labelled the natural rate of interest Wicksell's steady-state or long-term neutral interest rate (Chadha \& Perlman, 2014; Chetwin \& Wood, 2013). To clarify, the rate at which savings and investment are equal or aggregate demand equals aggregate supply, but not necessarily in long-run equilibrium, is the real rate of interest. Of interest for policy purposes is the neutral real interest rate, a short-run neutral rate that will cause inflation rates to neither to rise or fall in the year or two it takes for interest rates to have their full impact on inflation. Holding actual real interest rates above/below the short-run neutral interest rate would lower/raise inflation. In general, the neutral interest rate is consistent with a zero output gap and stable inflation. Clearly, and from our formulation, it will change over time due to shifts in productivity and varying preferences of individuals over saving and investment. The downward trend in the neutral interest rate since the financial crisis in the USA in 2008 has continued.

The "normal" rate of interest, according to Myrdal (Myrdal, 1962, p.36) in our language, is no different from a variable that must bring to equality the marginal equalities in the choice problems of both agents. In other words, we propose that the normal rate of interest at time $t$ is a number $r_{t}$ such that

$u^{\prime}\left(c_{t+1}\right) / u^{\prime}\left(c_{t}\right)=1 / 1+r_{t}=1 / 1+f^{\prime}\left(k_{t}\right)$

In order to expand on the notion of monetary equilibrium, we need to remind ourselves of the equivalent of the property of the criterion function of the consumer cited above for the producer. In contrast to the characteristic of the indirect utility function noted earlier, recall that the profit function is homogenous of degree one in the price of output and the input price. The problem, then, is that if an economy is not in a normal state, a series of adjustments generated by a change in the price vector might not be equilibrating because of this incommensurability in the criterion functions of the two 
agents. In order to sharpen the discussion in the next section with $\pi$ standing for the profit function, we define a monetary equilibrium, at time $t$, as a vector $\left(p_{t+1}^{*}, p_{t}^{*} ; m_{t+1}^{*}, m_{t}^{*} ; r_{t+1}^{*}, r_{t}^{*}\right)$,

such that

$$
\begin{aligned}
& v\left(p_{t+1}^{*}, p_{t}^{*} ; m_{t+1}^{*}, m_{t}^{*} ; 1+r_{t}^{*}\right) \geq v\left(p_{t+1}, p_{t} ; m_{t+1}, m_{t} ; 1+r_{t}\right) \nabla\left(p_{t+1}, p_{t} ; m_{t+1}, m_{t} ; 1+r_{t}\right) \in R^{5} \\
& \pi\left(p_{t+1}^{*}, r_{t+1}^{*}\right) \geq \pi\left(p_{t+1}, r_{t+1}\right) \nabla\left(p_{t+1}, r_{t+1}\right) \in R^{2} \\
& \pi\left(p_{t}^{*}, r_{t}^{*}\right) \geq \pi\left(p_{t}, r_{t}\right) \nabla\left(p_{t}, r_{t}\right) \in R^{2}
\end{aligned}
$$

The double condition that the profit function must fulfil is mandated by the future price level in the Euler condition of the consumer. It is no more than a consistency inclusion by virtue of contemporaneous elements in the information set of the firm. We emphasise that it is not the model-consistency requirement of rational expectations. In the language of Systems Theory, the profit function is feedback, that is, dependent on the value of the relevant state variables at the point of time under consideration, whereas the indirect utility function depends on anticipating information as well. Indeed, even absent the basis in Systems Theory, the inclusion of anticipations is sufficient to support Myrdal's strong non-neutrality theorem: that a gap exists in Wicksell's natural and monetary interest rate (Barbaroux \& Bellet, 2014). We conclude the representation of microeconomic persona with the worker. Now wages can substitute for money on the right hand side of the budget constraint. Consider a situation when the product is too cheap in relation to money prices and workers are pleased to take a cut in money wages in order to increase unemployment (Shackle, 1972). Echoing Lundberg at the beginning of this section, a general wage cut would leave workers with lower aggregate income from which they might spend less than before on consumption. With given output, prices would have to fall, leaving the original situation by and large unchanged. If, as Keynes pointed out, workers were willing to increase their propensity to consume out of given income, the dilemma would be resolved. Both employers and employees desire a wage which, in product terms, consists partly of a future provision. Employers, however, would be unwilling to enter into this social contract because they would need to provide nominal support for a real provision. On the other hand, the income-earners who make possible the accumulation of capital by saving a portion of their incomes do no more than lend their unspent cash balances to their employers. Differently put, the real wage desired by the suppliers of productive services at a higher level of employment and the real wage employers are willing and able to offer at the same level of employment are composed of a different consumption and non-consumption mix.

\subsection{A Myrdal-Wicksell Cumulative Process}

The equilibrating properties of this two-agent model cannot be taken for granted. According to Shackle, the bond price is at the heart of a web that weaves its way through the entire economy (Shackle, 1967). The interest rate is buffeted by uncertainty about 
the future prices of bonds given by borrowers in exchange for loans. It is always on the knife edge of opposing views between bulls and bears about its future movement. It depends on the valuation of stocks rather than flows. Money is also a stock. The exchange rate between money and bonds can change without any exchange between the two. Reverting to Wicksellian terms, consider an initial state when the money rate of interest is equal to the natural rate. Suppose the price vector changes by a factor $\alpha>1$. Then the market rate of interest must fall in relation to natural rate by the same factor to maintain optimality and the level of indirect utility remains unchanged. Profits in the present period, however, rise by the factor alpha. The greater profit possibilities of longer, more roundabout processes of production present themselves. As soon as the prices of consumption goods, $p_{t+1}$, actually increase, the optimism of entrepreneurs carries over into the interval $\left(p_{t+1}, p_{\mathrm{t}+2}\right)$. “... the process gets wind behind its sails and moves faster and faster. " (Myrdal, 1962, p. 25). Similar reasoning follows when prices change by a factor $\alpha$, where $0<\alpha<1$. Utility is unchanged but profits in the current moment fall by the same multiple and a cumulative downward spiral ensues over subsequent periods.

A fuller appreciation of Myrdal's innovation of monetary equilibrium is now possible. "The monetary equilibrium has the nature of being labile ... The monetary equilibrium is not a tendency at all, just the contrary. " (Myrdal, 1962, p.36, italics in the original). In other words, a cumulative upward or downward process is the sine qua non of a monetary equilibrium. At the same time, a monetary equilibrium "must be upheld by incessantly counteracting the influence of the intervening primary changes if the system shall not start rolling" (Myrdal, 1962, p.36). In our case, confining ourselves to two periods, to the primary change, $\alpha>1$, in period $t$, the monetary authorities must respond by increasing interest rates and reducing liquidity by the same factor at $t+1$. It might appear that the cancelling forces in the two parts of entrepreneur profits ensure equilibrium. However, in our policy intervention we have, effectively, introduced a $r_{t+1}^{*}=\alpha r_{t}^{*}$, where $\alpha>1$. In other words, our dynamic process goes into reverse in period $(t+1, t+2)$. The situation can be described in one of two ways. Prices ex post are different from prices ex ante. Else, in the jargon of credibility and reputation, in the new initial period $t+1$, consumers will find that the authorities have reneged on their tacit commitment to a $\alpha p_{t+1}$, where $\alpha>1$, made earlier. Looking forward, the homogenous-ofdegree-zero response of prices in the indirect utility function of agents is a deflation over the period $\left(\alpha p_{t+1}, \alpha p_{t+2}\right)$, where $0<\alpha<1$. The Wicksell connection is believed to be special here because, unlike other members of the school, he emphasised the influence of deviations of the money rate from the natural rate not on money growth and the price level but on the discrepancies between savings and investment that resulted. The main danger in rapid credit creation is not the rise in the general price level but on the distortionary impact on the intertemporal structure of relative prices (Laidler, 2007). 


\section{Conclusions}

Systems theorists distinguish between the synchronics and the diachronics of systems. The distinction is not different from the contrast Joan Robinson made between logical and historical time. The exponents of Swedish period analysis worked out the coherence and integrity of the economy as it existed in the formal present. Choices by the representative agent in the macroeconomics of the Stockholm School are made at the cusp of the moment when ex post results are given and plans ex ante had to be laid. Potential Paretoimproving barter bargains of goods today for goods tomorrow might exist but would be of no interest to households as a class and firms as a class. In order to command consumer goods in future, households must acquire a store of value. Savings means an increase in the demand for goods sometime in the future. However, the emergence of notional excess demand for future dated commodities cannot be effectively communicated to producers. It is not that information is imperfect or dispersed in the private information sets of agents but that the circuits do not exist. Existing markets cannot perform any consistency check on the multi-period plans of consumers and producers. Markets for current commodities exist. There is no market or price for savings. However, a market for credit exists. Given a certain willingness to give and take credit on the part of the agents concerned, interest rates must be determined by the forces of demand and supply. According to the Stockholm school, the 'natural rate of interest' is not related to technical productivity but must be understood as expected profitability. The latter, in turn, must approximate Keynes' marginal efficiency of capital. The rate of interest is simply the price of credit and can therefore be influenced by the banking system. In disequilibrium sequence analysis the economic process is represented by an array of single periods that are not in equilibrium. In each period, however, there are constant rules of conduct that determine how the ex post results from one period influence the ex ante plans for the next period. These actions of various agents can be regarded as the equilibrium notion within disequilibrium sequence analysis. The inequality between planned savings and planned investment sets in motion a process which makes realised income differ from expected. The difference between the two is unexpected income. The end of the process is not a new equilibrium. The coordination problem remains unsolved.

\section{References}

Barbaroux, N. and M. Bellet (2014), 'Monetary Policy and Value Judgements: Did we forget Myrdal's legacy?'Groupe D’Analyse de Théorie Économique Lyon-St Etienne Working Paper 1408 February 2014

Barber, W.J. (2009), Gunnar Myrdal, London: Palgrave Macmillan

Boianovksy, M., and H-M Trautwein (2006), 'Wicksell after Woodford', Journal of the History of Economic Thought,28

Calvo, G. (2012), 'The price theory of money, Prospero's liquidity trap and sudden stops: back to basics and back',NBER Working Paper 18285, August 2012

Chadha, J., and M. Perlman (2014), 'Was the Gibson Paradox for real? A Wicksellian study of the relationship between interest rates and prices', The London School of Economics and Political Science, Economic History Working Paper No 204/2014 
Chetwin, W. and A. Wood (2013), 'Neutral interest rates in the post-crisis period', ReserveBank of New Zealand Analytical Notes AN2013/07, November 2013

Dequech, D.(2012), 'Post Keynesianism, Heterodoxy and Mainstream Economics', Review of Political Economy,24

Epper, T., H. Fehr-Duda, H. andA. Bruhin (2010), 'Viewing the Future through a Warped Lens: Why Uncertainty Generates Hyperbolic Discounting',Institute of Empirical Research in Economics, University of Zurich, Working Paper No. 510, September 2010

Faxén, K.O. (1991), 'Sequence analysis and optimization',inL. Jonung(ed.) The Stockholm School of Economics Revisited, Cambridge: Cambridge University Press

Goodhart C.A.E. (2009), 'Whatever became of monetary aggregates?', in G.Hammond, R.Kanbur, and E.Prasad (eds.) Monetary Policy Frameworks for Emerging Markets, Cheltenham: Edward Elgar

Kakarot-Handtke, E. (2010), 'Axiomatic Basics of e-Economics', MPRA Paper No. 4431, July 1,2010

Laidler, D. (2006), 'Woodford and Wicksell on Interest and Prices: The place of the pure credit economy in the theory of monetary policy', Journal of the History of Economic Thought,28

- (2007), 'Financial Stability, Monetarism and the Wicksell Connection', The University of Western Ontario RBC Financial Group Economic Policy Research Institute Working Paper No.2007-3

. (2012), 'Two Crises, Two Ideas and One Question', University of Western Ontario

RBC Financial Group Economic Policy Research Institute Working Paper No.2012-4

Lavoie, M. (2012), 'Perspectives for Post Keynesian Economics', Review of Political Economy, 24

Leijonhufvud, A. (1969), Keynes and the Classics, IEA Occasional Paper 30, The Institute of Economic Affairs, Westminster: Great Britain

(1981), Information and Coordination: Essays in Macroeconomics, New

York: Oxford Economic Press

Lindahl, E. (1970), Studies in the theory of money and capital. New York: Augustus M. Kelley.

Lundberg, E. (1937), Studies in the theory of Economic Expansion, P.A. Norstedt \& Söner: Stockholm . (1968), Instability and Economic Growth, New Haven: Yale University Press . (1996), The Development of Swedish and Keynesian Macroeconomic Theory and its impact on economic policy, Cambridge: Cambridge University Press

Mazzocchi,R., R. Tamborini, R. andH-M Trautwein (2009),'The Two Triangles: what did Wicksell and Keynes know about macro that modern economists do not (consider)?',University of Trento, Department of Economics Working Paper No.6

Myrdal, G. (1962), Monetary Equilibrium, New York: Augustus M. Kelley

Sandelin, B. andH-M Trautwein (2008), A Short History of Economic Thought, London: Routledge

Shackle, G.L.S. (1954), 'Foreword', to Wicksell, K. Value, Capital and Rent, 1954, London: George Allen and Unwin Ltd . (1967), The Years of High Theory: Invention and Tradition in Economic 
Thought, Cambridge: Cambridge University Press

(1972),Epistemics and Economics: A Critique of Economic Theory, London:

Cambridge University Press

. (1978),An Economic Querist, London: Cambridge University Press

Siven, C-H. (1991), 'Expectation and plan: The microeconomics of the Stockholm School', in L. Jonung(ed.) The Stockholm School of Economics Revisited, Cambridge: Cambridge University Press

Tobon, A. and N. Barbaroux (2015), Credit and Prices in Woodford's New Neoclassical Synthesis', Economic Thought, 4

Turk, M.H. (2012), 'The mathematical turn in Economics: Walras, the French mathematicians, and the road not taken',Journal of the History of Economic Thought,34

Van den Hauwe, Ludwig (2015) Understanding Financial Instability: Minky versus the Austrians, MPRA Paper No 61838 posted February 5, 2015

van Eaghen, P-H. (2014), 'Why DSGE analysis cannot accurately model financial-real sector interaction', real-world economic review, $\mathbf{6 7}$

Weber, A., W. Lemke, and A. Worm (2008), 'How useful is the concept of the natural rate of interest for monetary policy?', Cambridge Journal of Economics,32

Woodford, M. (2005),Interest and Prices. Princeton: Princeton University Press 